\title{
震災時における救急車の駆けつけ搬送圏域の 救命制約時間信頼性評価
}

\author{
柳沢 吉保 1 -古本 吉倫 2 高山 純一3 \\ 南澤 智美 4 ・尾曽 真理恵 5 \\ 1正会員 長野工業高等専門学校 環境都市工学科（テ381-8550 長野県長野市徳間716） \\ E-mail: yana@nagano-nct.ac.jp \\ 2正会員 長野工業高等専門学校 環境都市工学科（テ381-8550 長野県長野市徳間716） \\ E-mail:furumoto@nagano-nct.ac.jp \\ 3フェロー会員 金沢大学 理工学域 環境デザイン学類（†920-1192 金沢市角間町） \\ E-mail: takayama@staff.kanazawa-u.ac.jp \\ 4非会員＼cjkstart長野県警（†381-1232 長野県長野市松代町西条3929） \\ E-mail: yana@nagano-nct.ac.jp \\ 5非会員 飯田市役所（†395-8501 長野県飯田市大久保町2534 \\ E-mail: chiikikeikaku@city.iida.nagano.jp
}

\begin{abstract}
東日本大震災による甚大な被害は，我が国の地震被災時の対応に対する大きな問題提起となった．国内 にも系魚川一静岡構造線をはじめ, 周辺地域に大きな被害をもたらす可能性がある活断層が多数分布して いるため，地震発生時の対策を至急検討しなければならない。とくに人命にかかわる救援活動では，消防 署・分署などの救急拠点や搬送先病院間の救急駆けつけ搬送において, 救急車両を各消防署に適切に配置 し，被災現場まで配車を効果的に行うことが求められる．本研究では，リンク交通量に基づく交通量の変 動を考慮した救命制約時間信頼性評価に基づき，長野都市圈交通ネットワークにおける救急駆けつけ搬送 時の課題を明らかにするとともに，その対応策の方向性について示す.
\end{abstract}

Key Words : emergency conveyance service, earthquake victim, travel time reliability, accessibility

\section{1. はじめに}

\section{(1) 本研究の背景}

東日本大震災による甚大な被害は，我が国の地震被災 時の対応に対する大きな問題提起となった．国内では大 地震発生の引き金となる活断層が存在する．大規模な被 災が懸念されている東海地震，東南海地震などのプレー 卜境界型地震や，内陸部に多く存在する活断層を原因と する地震に対して，被害想定が積極的に行われ，自治体 等でその対策が検討されている，長野県にも活断層が多 く分布しているが，主要断層である系魚川一静岡構造線, 信濃川断層帯，伊那谷断層帯，阿寺断層帯はとくに県内 に大きな被害をもたらす可能性があるため，地震発生時 の対応を至急検討しなければならない.

大規模地震による被害事例として，阪神・淡路大震災 では，被災地外からの救急応援（消防，警察，自衛隊） が，道路の閉塞および迁回した道路の交通渋滞に巻き込 まれ，被災現場までの移動に時間がかかったことは救助
活動が大幅に遅れる一因となった．道路啮滞の最大の原 因は，地震被荻直後では落橋などによる幹線道路と鉄道 の寸断であった．時間の経過とともに安否確認や見舞い など，救助以外の自動車の殺到が渋滞に拍車をかけた. とくに人命に大きくかかわる被災直後の救助部隊を現場 や搬送先まで交通渋滞に巻き込まれないような誘導を効 率的に行うための消防署・分署などの救急拠点や救護所, 搬送先病院の配置を確認する救急駆けつけ搬送体制を構 築しておくことが重要な課題であるとされた.

長野市では，第 4 次長野市総合計画において，災害に 強いまちづくりおよび防災対策の推進が主要政策の一つ とされている．市民アンケートの「消防や救急救命活動 が迅速に行われているか」の問に対して, 現状で達成し ているとした回答は 63.4\%であり，目標值 70\%を下回 っているのが現状である，とくに，地震発生による被災 時の対応として消防，救急，救助体制の充実が求められ ている. 現在長野市では, 地震発生時の救急体制として 市内に消防署・分署 14 ヶ所，救護所 13 ヶ所，搬送先で 
表-1 救急駆けつけ搬送に関する既往研究の概要

\begin{tabular}{|c|c|}
\hline 平常時 & 非常時(災害時) \\
\hline 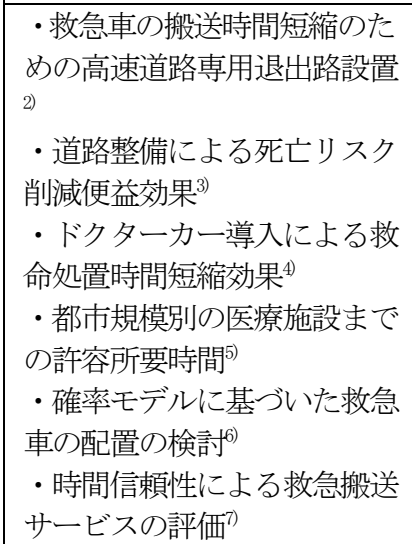 & 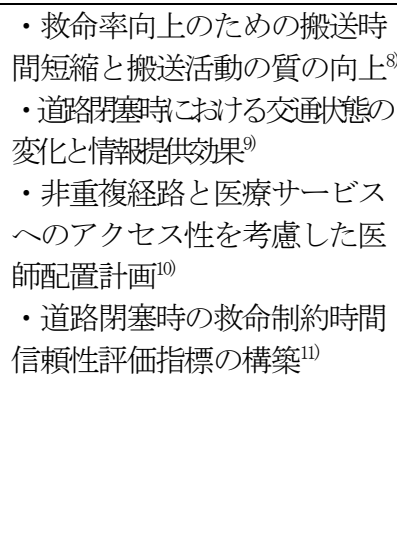 \\
\hline
\end{tabular}

ある後方病院 8 ケ所が指定されている. 消防署・分署に 出動要請があれば，救急車は救護所も含めた被災地に向 かい，重傷者と判断されれば後方病院に搬送する。駆け つけ搬送を効率的に行って救命率を上げるためにも，地 震被災発生前に市内のどの場所でどれだけの重傷者が発 生するのかを想定しておく必要があるある。平成 14 年 度長野県地震基礎調查報告 ${ }^{1}$ によると，長野市における 被災対象となる橋梁は 88 箇所, 盛り土は 7 箇所, 斜面 248 箇所である.このうち, 信濃川断層帯による地震で 不通となる深刻な被害は, 橋梁 5 箇所, 盛り土 3 箇所, 斜面 57 箇所とされるが，救急車両を被災現場へ配車す るための消防署・分署などの救急拠点および後方病院な どの搬送拠点が必ずしも，被災位置や重傷者数を考慮し て配置されているわけではない，そこで，重傷者の発生 数を想定した被災位置を考慮した消防署・分署および搬 送先後方病院の組み合わせを検討する必要がある.

\section{(2) 既往研究と本研究の位置づけ}

救急駆けつけ搬送に関する既往研究は平常時と非常 時について検討されてきた. 概要を表-1に示す．平常時 では，搬送時間短縮のための高速道路専用退出路設置， 道路整備, ドクターカー導入効果を検討した研究と, 消 防署から医療機関までの救急車両の移動時間を確率的に 評価し, 適切な救急車両の配置など救急拠点配置が検討 されてきた。一方，非常時(災害時)では，道路閉塞時の 情報提供効果，駆けつけ搬送に要する所要時間の時間信 頼性評価，医療機関へのアクセス性を考慮した医師配置 等が検討されてきた.

地震被災による道路閉塞によって, 通勤通学などの

日常的な行動のほかに，重傷者の病院搬送および救援物 資輸送など，多くのトリップが影響を受ける．日常生活 を取り戻すためには，道路閉塞部の復旧に早急に取り組 む必要があるが，人命にかかわる救命救急活動，救援物 資輸送は道路の復旧を待つことはできない. とくに救急
活動は，被災者に対して早急に対応が求められる. 寸な わち, 被災直後から救急活動が開始されるため, 道路ネ ットワーク上の閉塞地点の有無を考慮した適切な駆けつ け搬送行動が求められる. 被災時の駆けつけ搬送を扱つ た主な研究はつぎのとおりである。陶山ら 塞時の交通流動変化を考慮した交通情報の最適空間配置 を検討している．陶山らも指摘しているように被災によ る道路閉塞時には最短経路が大きく変わることから, 救 急搬送には，最短経路の探索と誘導が必須と考えられる. ただし，仮想モデルを対象としたシミュレーションによ る知見が主であり，実際のエリアを対象に生起する地震 の規模および交通ネットワークエリアの被災の実情に基 づいた知見は得られていない，瀬戸ら ${ }^{10)}$ は，非重複リ ンクを考慮した都市との連結性と都市内の医師数に基づ くアクセシビリティを構築し, ネットワーク形状および 医療サービスの制約による最適な医師配置パターンの変 化を検討している. しかしながら，救急車両の駆けつけ 搬送行動を明示的に導入し，消防署・分署と被災地，後 方病院間を適切に結び付ける実証的な検討までは至って いない，尾曽ら ${ }^{111}$ は，駆けつけ搬送時間を明示的に扱う とともに，救命制約時間を時間信頼性で評価している. しかしながら，秦ら命が指摘しているように，被災地の 重傷者数に対応可能な救急車両数を考慮していない，一 方，平常時における駆けつけ行動を明示的に扱っている 研究として, 稲川 (ㅎは, 出動要請一の対応可能性をマ ルコフ連鎖で表現し，移動時間と準備時間の和で表わさ れる呼び出し地点までの対応時間分布を，センター問題， 最大被覆問題など $5 つ の$ 施設配置指標に基づき求めてい る. また，救急サービス供給の公平性と救命率の関係を 考察している. しかしながら, 移動時間および準備時間 を統計的な平均值で固定的に与えているため, 道路の渋 滞状況を表現できないことと，駆けつけ搬送行動を明示 的に扱っていない，高山ら〕は，駆けつけ搬送時間をリ ンク交通量に基づく所要時間関数で明示的に扱うととも に，リンク交通量に基づく所要時間分布を導出すること で，消防署から医療機関までの到達時間信頼性による救 急搬送サービスの評価法を示し, 救急拠点管轄エリアの 最適配置を検討している.

以上より, 救命率の向上に重点を置いた場合, 地震 被災直後の道路閉塞時を評価対象とする必要がある. 被 災地に対する消防署および後方病院の選定を行うために は，救急駆けつけ搬送時間を明示的に扱うとともに，移 動中の所要時間の変動を考慮した時間信頼性に基づいた 評価を導入する必要がある，さらに，秦ら ${ }^{8)}$ の指摘のよ うに同時多発的に発生する被災者の救命を対象とすると， 発生する被災者数と対応できる救急車両数も考慮する必 要がある. 以上を考慮し本研究では, 長野県北部に大き な被害を及ぼすとされる信濃川活断層が，長野都市圈交 


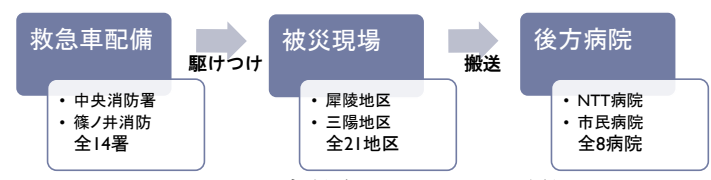

図-1 長野市救急駆けつけ搬送体制

通ネットワークと長野市の被災時救急駆けつけ搬送行動 に与える影響を検討寸る，具体的には，(1)信濃川活断 層を震源とした地震発生が長野都市圈交通施設へ及ぼす 被害予測を整理し，建物倒壊に基づく被災による重傷者 数を予測する，（2）長野市の地震被災時の救急体制と本 研究の枠組みを示す，(3) リンク交通量に基づく交通量 の変動を考慮した OD 間経路選択モデルを示す，(4)長 野都市圈交通ネットワークにおける救命制約時間信頼度 に基づく駆けつけ搬送竹叱师个(以下 AC と記述する)指 標を示す，（5）長野市交通ネットワークをケーススタデ イとした長野都市圈内駆けつけ搬送 $\mathrm{AC}$ を検討する.

\section{2. 長野市救急駆けつけ搬送体制と 本研究のフレーム}

\section{（1）長野市救急駆けつけ搬送体制}

長野市の搬送体制は図-1に示すとおりである。市内に は消防署・分署が全14ヶ所，後方病院が全8ヶ所配置さ れている．救急車両によって搬送を行う被苂者は，倒壊 した家屋等の下敷きになる，あるいは大量の出血がある など，自力では病院等まで移動できない重傷者が対象と なると考えられる．才なわち救急車が対応寸ることにな る主な駆けつけ先は重傷者が発生した地点(被災現場) と なる．以上を考慮し，駆けつけ搬送プロセスは図-1に示 すとおり，1) 重傷者発生の連絡を受けたのち救急車両が 消防署・分署を出発する，2) 重傷者が存在する被災現場 一駆けつける，3) 重傷者を後方病院一搬送する，である. なお，長野市では，救護所となる中学校を指定している が，避難場所としての役割を主としているため，本搬送 プロセスでは考慮しない.

\section{（2）駆けつけ被災地区と分析対象時点}

長野市の救急駆けつけ搬送体制において，おもな駆 けつけ先は, 出動要請がなされる市内の不特定の被災現 場となる.このことを考慮しつつ，本研究では時間信頼 性評価を便宜的に行うため，被災現場は，行政機能を有 し，最小行政界である地区単位ごとに一つずつ設置され ている支所で代表させることとする，長野都市圈の被災 現場対象地区は21地区あるが，交通ネットワークデータ は，人が移動する際の出発地点と到着地点を集計した平 成13年度のPT調査しかないため, 平成17年に長野市に 合併した，鬼無里地区，中条地区，戸隠地区，大岡地区 の4地区を除いた地区を対象として分析評価する. 各地
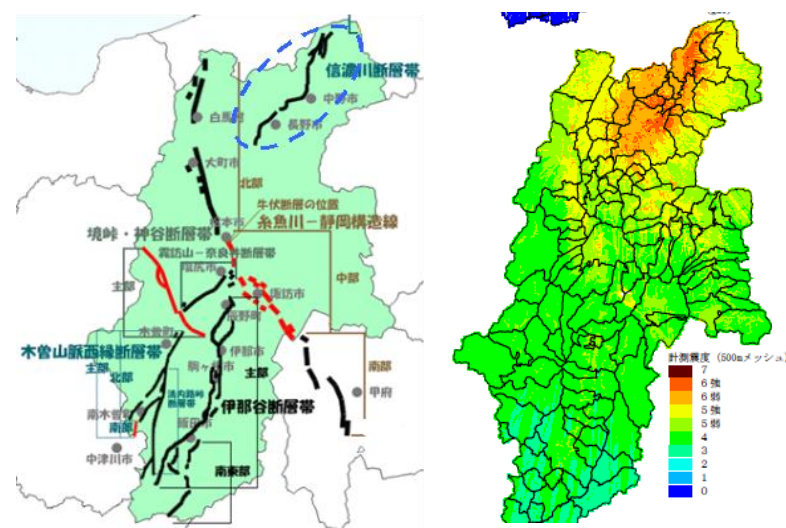

図-2 長野県周辺の活断層と信濃川断層帯による震度分布 ${ }^{1)}$

区には，診療所など開業医が存在するが，それらは救急 駆けつけ搬送体制のなかで後方病院としては位置付けら れていない．またどの程度被災重傷者に対応できるか不 明であることと，医師自身が地震被災する可能性もある ことを考慮する必要がある，そこで，本研究では，救命 に間に合う病院搬送時間到達確率を表わす時間信頼性の 評価分析を行うが，分析対象は，救急車が各消防署・分 署から出動し，重傷者が存在する被災現場がある地区の 支所に駆けつけ，重傷者を後方病院に搬送する信頼性と する．また，被災重傷者の救命率を上げることを目的に， 被災直後の道路閉塞による通行不可を考慮した救急駆け つけ搬送行動を検討するため，通常時のネットワーク上 の交通状態において，被災可能性のあるリンクが閉塞し， ルート連結が途絶された時の利用可能なルートの時間信 頼性を検討することとする.リンク閉塞時の交通行動は, 閉塞リンクの復旧状況や，交通情報及び経路誘導によっ て大きく変化するので, 別途扱うのが妥当と判断した.

\section{3. 信濃川断層による被害予測}

\section{(1) 信濃川断層の概要}

長野県に影響を及ぼす主な地震は，糸魚川一静岡構造 線, 信濃川断層帯, 伊那谷断層帯, 阿寺断層系による地 震，および東海地震である。このうち，おもに長野県北 部に大きな影響を与える信濃川断層帯を震源とした地震 を対象に，長野都市圈交通ネットワークおよび建築物に 与える影響を分析する。信濃川断層地震による長野県内 震度分布を図-2に示寸，長野県地震対策基礎調査 ${ }^{1}$ によ ると断層の長さは $43 \mathrm{~km} ，$ 断層の幅は $21 \mathrm{~km}$ と大きく，断層 の範囲は飯山市から長野市へとつながっている．地震動 が最大となる断層上端深さは $3 \mathrm{~km}$, 最大想定地震規模は M7. 5 で，計測震度は平均值 5.9 , 最大值は6.2にも達する と予測されている. 本断層による地震被害は建築物の倒 壊による人的被害のほかにも，交通施設およびライフラ インにも甚大な被害を与えると予測されている. 
表-2 信濃川断層による地震被災時被害生起箇所

\begin{tabular}{|l|r|r|r|}
\hline & \multicolumn{1}{|c|}{ 盛土 } & \multicolumn{1}{|c|}{ 切土 } & \multicolumn{1}{|c|}{ 橋梁 } \\
\hline 被災の対象となるリンク数 & 7 & 248 & 88 \\
\hline 通行不可となる箇所 & 3 & 39 & 5 \\
\hline
\end{tabular}

\section{（2）長野都市圏交通ネットワークの被害予測}

地震により交通ネットワークに与える被災事象はリン ク閉塞による通行不可を考慮する。平成 14 年長野県地 震対策基礎調査 ${ }^{1)}$ では，液状化・地すべり・落石崩壊お よび過去の地震被害状沉を考慮し，表-2に示すとおり 今回対象の道路被災箇所として，盛土，切土，橋梁部に おいて通行制限も含む道路通行不可箇所が予測されてい る. 災害対象となるリンクでは最も切土が多く, 通行不 可個所も最も多いが，盛土が存在するリンクでは，通行 不可となる可能性が高いことがわかる．なお，ここで通 行制限とは大幅な補強後に使用可能となるため, 被災直 後の駆けつけ搬送時には通行不可として扱うこととする.

\section{(3) 信濃川断層被災時の重傷者数}

信濃川断層帯を震源とする地震被災時の，救命処置が 必要な地震被災重傷者数を，前章で示したとおり支所が 設置されている 21 地区ごとに算出する. 平成 14 年長 野県地震対策基礎調査報告書で提示された住宅被害率お よび重傷者数算定式を用いて，以下のアルゴリズムで各 地区で発生する地震被災重傷者数を算出する．なお算定 には，メッシュデータとして提供されている建物種別 全・半壊被害想定データを用いた。

1) 地区 $j$ の全建物数 $F_{j}$ を長野市統計書を用いて調べる. 2) 地区 $j$ を構成する $500 m \times 500 m$ メッシュを抽出する. 3) 地区 $j$ 内の木造・非木造建物の全・半壊メッシュ数を 数える.

4) 地震対策基礎調査報告書の住宅被害率算定式に基づき, 地区 $j$ 内の住宅被害率 $H_{j}$ は，\{(全壊メッシュ数 $+1 / 2$ 半 壊メッシュ数)/対象地区内全メッシュ数 $\}$ で算出する. 長野都市圈内の住宅被害率分布図を図-3に示寸.

5）地区jにおける地震被災重傷者の発生率は,

$$
\log R_{j}=0.676 \cdot \log H_{j}-1.409
$$

を用いて算出する. ここで, $R_{\mathrm{j}}$ : 重傷者数. 各地区の地 震被災重傷者を表-3に示寸，なお，本推計方法では，重 傷者をさらに重傷度(心臓停止・呼吸停止・大量出血)別 に推計することはできない，そこで本手法で推計された 重傷者は地震による被災を考慮し，大量出血者とした。

\section{4. 長野市交通ネットワ一クの時間信頼性評価}

\section{(1) 救急車両の救命制約時間信頼性評価フロー}

1)交通ネットワークの初期状態作成：H13年度長野都市 圈PT調査データを用いる. 分割配分法による配分交通

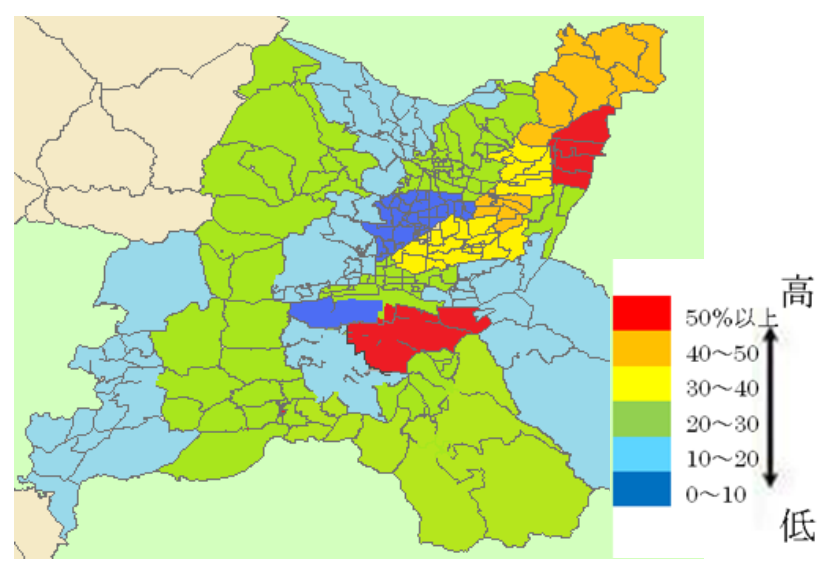

図-3 長野都市圈住宅被害率分布図

表-3 各地区で発生する重傷者数

煡物一戸当たりの居住者は 2.5 人.

\begin{tabular}{|c|c|c|c|c|}
\hline 地区名 & 建物数 & $\mathrm{H}_{\mathrm{f}(\%)}$ & $R_{i}(\%)$ & 重傷者数 \\
\hline 三輪 & 26314 & 3.8 & 0.1 & 63 \\
\hline 芋井 & 994 & 22.4 & 0.3 & 8 \\
\hline 古牧 & 10385 & 30.4 & 0.4 & 102 \\
\hline 柳原 & 2677 & 20.7 & 0.3 & 20 \\
\hline 古里 & 5358 & 34.8 & 0.4 & 58 \\
\hline 長沼 & 901 & 93.3 & 0.8 & 19 \\
\hline 浅川 & 2803 & 12.3 & 0.2 & 15 \\
\hline 若柣 & 7847 & 26.5 & 0.4 & 70 \\
\hline 豊野 & 3541 & 40.7 & 0.5 & 42 \\
\hline 安茂里 & 12763 & 12.0 & 0.2 & 67 \\
\hline 小田切 & 515 & 11.9 & 0.2 & 3 \\
\hline 七二会 & 838 & 27.2 & 0.4 & 8 \\
\hline 芹田 & 11772 & 20.6 & 0.3 & 89 \\
\hline 大豆島 & 4564 & 29.6 & 0.4 & 44 \\
\hline 朝陽 & 5794 & 44.2 & 0.5 & 73 \\
\hline 篠ノ井 & 15353 & 24.1 & 0.3 & 129 \\
\hline 信更 & 1020 & 16.3 & 0.3 & 7 \\
\hline 松代 & 6901 & 20.9 & 0.3 & 5 \\
\hline 若穂 & 4343 & 15.3 & 0.2 & 52 \\
\hline 川中島 & 9833 & 12.7 & 0.2 & 27 \\
\hline 更北 & 11947 & 28.1 & 0.3 & 53 \\
\hline
\end{tabular}

量の計算から得られた各経路をドライバーが選択可能な 経路とする．さらに配分された交通量に基づき，リンク 平均所要時間と分散を初期状態として算出する.

2)ドライバーの予測所要時間分布の更新 : ドライバーは 経験した利用経路の実平均所要時間および分散を考慮し, 予測平均所要時間およびその分散からなる予測所要時間 分布を更新する．今回の予測值は前回の予測值と実測值 との差を考慮し，次式により更新するものとする．

$$
\begin{aligned}
& E\left(\tilde{t}_{r, n}\right)=E\left(\tilde{t}_{r, n-1}\right)+\omega_{e} \times\left\{E\left(t_{r, n-1}\right)-E\left(\tilde{t}_{r, n-1}\right)\right\} \\
& V\left(\tilde{t}_{r, n}\right)=V\left(\tilde{t}_{r, n-1}\right)+\omega_{v} \times\left\{V\left(t_{r, n-1}\right)-V\left(\tilde{t}_{r, n-1}\right)\right\}
\end{aligned}
$$
ここで、 $E\left(t_{t, n}\right)$ およよ゙ $V\left(t_{t, n}\right): n$ 回目の経路 $r$ の実平均所要 時間およびその分散. $E\left(\tilde{t}_{r, n}\right)$ および $V\left(\tilde{t}_{r, n}\right): n$ 回目の経 路 $r$ の予測平均所要時間およびその分散. $\omega_{e}$ および $\omega_{v}$ : それぞれ所要時間およびその分散の予測值と実測值との 差に対する重みとする.

3) ドライバーの経路選択行動 : ドライバーは経路選択に あたり，予測した所要時間分布に基づき，当該経路にて 実現が期待される予測平均所要時間よりも多めに見積も 


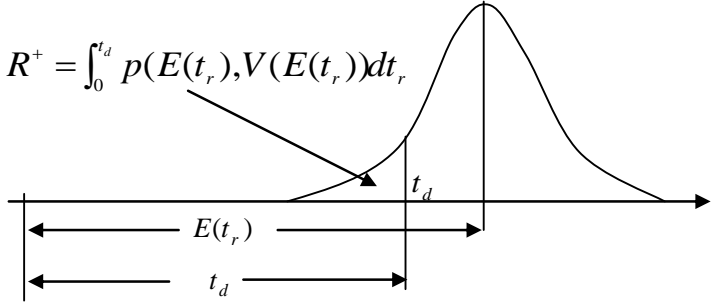

図-4 救命制約時間 $t_{d}$ の時間信頼性

った所要時間と，その所要時間を超過してしまう確率を 考慮した経路選択負効用を知覚する ${ }^{12)}$ 。そこで，式(4) で表される経路選択負効用が最小になる見積所要時間を 知覚し，複数の選択可能経路の中から，経路選択負効用 が最小になる経路を選択することになる。

$$
U\left\{\tilde{t}_{r, n}\left(\hat{t}_{r, n}\right)\right\}=\beta \times \hat{t}_{r, n}+\gamma \times F\left\{\tilde{t}_{r, n}\left(\hat{t}_{r, n}\right)\right\}
$$

ここで, $\hat{t}_{r, n}$ : 見積所要時間. $F\left\{\tilde{t}_{r, n}\left(\hat{t}_{r, n}\right)\right\}$ : 見積所要時間 超過確率. $U\left\{\tilde{t}_{r, n}\left(\hat{t}_{r, n}\right)\right\}$ : 経路 $r$ の負効用. ここで長野都 市圏を対象とした既往研究 ${ }^{13)}$ に基づき，効用関数パラメ ータ Bは-0.054, $\gamma$ は-2.825 とする.

経路選択行動は，式(5)に基づくロジットモデルを用 いて，各経路の選択確率 $p_{n,}$ を算出する.

$$
p_{r, n}=\exp U\left\{\tilde{t}_{r, n}\left(\hat{t}_{r, n}\right)\right\} / \sum_{r^{\prime}=1}^{M} \exp U\left\{\tilde{t}_{r^{\prime}, n}\left(\hat{t}_{r^{\prime}, n}\right)\right\}
$$

ここで， $r$ : 経路 $(r=1, \ldots, M)$. 得られた経路選択確率に基 づいて各 ODの経路およびリンク交通量を算出する.

4) 収束の確認 : 2) 3) の過程を繰り返し当日の経路交通 量と前日の経路交通量の差が許容範囲 $\varepsilon$ 以内であれば収 束状態として，5)で示す時間信頼の計算に移行する.

5) 時間信頼性評価 : 被災による重傷患者の駆けつけ搬送 先病院までの救命制約時間を $t_{d}$ とする. 各経路の実所要 時間分布は，収束状態後に得られた実平均所要時間 $E\left(t_{m, n}\right)$ および分散 $V\left(t_{m, n}\right)$ により与えられる。経路 $r$ において救命 制約による指定所要時間までに駆けつけ搬送行動が完了 する確率 $R^{+}$を時間信頼性指標とする. 救命制約時間 $t_{d}$ の 時間信頼性の概念図を図-4に示す。

\section{（2）リンク所要時間およびその平均と分散の算出方法}

前節(1)におけるリンク所要時間の算出には，経路選 択行動により生起したリンク交通量を用いる。交通量が 交通容量に近づくほど，混雑が増大する現象を再現する 式(6)の BPR 関数を用いて所要時間を算出する.

$$
t_{l}=t_{l 0} \times\left\{1.0+\kappa \times \eta \times\left(x_{l} / C_{l}\right)^{v}\right\}
$$
ここで、 $l$ : リンク $l . t_{l}$ : 所要時間. $t_{l 0}$ : 自由走行時間. $x_{l}$ : 交通量, $C_{l}$ : 交通容量. BPR 関数パラメータとして, 米国道路局の $\kappa=0.15, v=4$ を用いた。 また，救急車両 と一般車両を区別するため，交通量軽減係数 $\eta$ を乗じた。 交通量軽減係数 $\eta$ は一般車両では 1.0 である. 既往研究 14)により, 救急車両で現場まで駆けつける場合, 前方の 車両の影響が少なく信号を無視できるため, 一般車両よ
り速く到達できることを考慮して 0.35 と設定した. 一 方，後方病院までの搬送は，重傷者を乗せているので， 安全を考慮し 0.70 と設定した. 本研究では日常的に交 通量が大きく変動することを考慮するため, 式(6)の $x_{l}$ は 確率変数として扱う。ここで，積率母関数の性質を用い ることで, 実平均所要時間の期待值(平均值)は式(7), そ の分散は式(8)で表わすことができる.

$$
\begin{gathered}
E\left(t_{l}\right)=t_{l 0} \times\left\{1.0+0.15 \times \eta \times E\left(x_{l}{ }^{4}\right) / C_{l}{ }^{4}\right\} \\
V\left(t_{l}\right)=\int_{-\infty}^{\infty} t_{l}{ }^{2} p\left(t_{l}\right) d t_{l}-E\left[t_{l}\right]^{2}
\end{gathered}
$$

\section{（3）救命制約時間信頼度を用いた救命ACの算定}

被災時において同時多発的に発生する被災者の救命率 を上げるためには，駆けつけ搬送時間だけでなく，被災 地で発生する重傷者数と, 重傷者の搬送に対応できる救 急車両数も考慮する必要がある ${ }^{8)}$. 本研究で用いる時間 信頼性を考慮した駆けつけ搬送の評価指標(以下，救命 $\mathrm{AC}$ と呼ぶ)は, 各地区で発生が予想される重傷者数, 各消防署・分署に配備されている救急車両台数を考慮し, 以下のように構築する.

a)ある消防署・分署の救急車両が救命制約時間内に重傷 者の救命に対応できる可能性は，消防署・分署の救急車 両が，要請のあった被災地区に救命制約時間内に駆付け， ある後方病院に搬送できる確率を用いて式(9)で表わす。

$$
E_{i} \times p_{i j k}\left(t \leqq t_{d}\right)
$$

ここで、 $i$ : 消防署・分署番号, $j:$ 被災地区番号, $k$ : 後 方病院, $E_{i}$ : 救急車両数, $p_{i j k}\left(t \leqq t_{d}\right)$ : 要請のあつた被災地 区 $j$ に救命制約時間 $t_{d}$ 内に駆付け, 後方病院 $k$ に搬送で きる確率. $p_{i k}\left(t \leqq t_{d}\right)$ の算定には，救急駆けつけ搬送所要 時間関数式(6)を用いる.

b) ある消防署・分署から出発した救急車両が，被災地に 駆けつけ，後方病院に搬送する場合の救命ACは，被災 地区で発生した重傷者数を考慮した，被災者一人当たり に，消防署・分署から駆けつけた急車両が割り当てられ る可能性を表わす式(10)で算出する.

$$
C_{j \mid i, k}=E_{i}\left\{\frac{p_{i j k}\left(t \leq t_{d}\right)}{P_{j}}\right\}
$$

ここで， $P_{j}$ : 重傷者数. そこで被災地 $j$ の重傷者が救命 制約時間内に後方病院へ搬送される可能性を表す総救命 $\mathrm{AC}$ は，以下の指標 $C_{j}$ で表すこととする.

$$
C_{j}=\sum_{i=1}^{N} \sum_{k=1}^{K} E_{i}\left\{\frac{p_{i j k}\left(t \leq t_{d}\right)}{P_{j}}\right\}
$$

ここで， $C_{j}$ : 都市圈内の消防署・分署から出動した救急 車両が被災地区 $j$ の重傷者を救命制約時間内に都市圈内 後方病院搬送できる可能性を示寸総救命 $\mathrm{AC} . E_{i}$ : 消防 署・分署 $i$ が所有する救急車両台数. $p_{i j k}\left(t \leqq t_{d}\right)$ : 消防署・ 分署 $i$ から出動した救急車両が被災地区 $j$ の重傷者を救 命制約時間 $t_{d}$ 内に後方病院 $k$ に搬送できる時間信頼度. 
$P_{i}:$ 地区 $i$ 内で発生した重傷者数.

式(10)は救命制約時間信頼度が最も高くなる消防署・ 分署および後方病院の組み合わせを明らかにする, 効果 的な救急車両の出動要請を行う, 消防署・分署および後 方病院の被災地への適切な救急駆けつけ搬送サービス圈 域を検討することができる指標と考える. 一方，式(11) は，各被災地ごとに救命制約時間信頼度が高い駆けつけ 搬送サービスを享受できるよう近接した消防署・分署お よび後方病院がどれだけあるかを判断するための指標で あり，消防署・分署および後方病院の配置および指定数 を検討できる指標と考えられる. なお，配置問題は別途 検討するため，以下では，式(10)を用いた検討を行う.

\section{5. ケーススタディ}

\section{(1) ケースの設定}

カーラーの救命曲線から死亡率が $50 \%$ まで上がってし まう確率は重篤度ごとに，1)心臓停止後約3分，2)呼吸停 止後約10分，3)多量出血後約30分と設定されていること がわかっている ${ }^{11)}$. 先に論じたとおり，被災者は大量出 血者とし，ケーススタディとして救命率50\%の信頼性を 評価することとし，制約時間を30分とした ${ }^{11)}$.また交通 行動モデル，リンク所要時間関数，救急車交通量軽減等 のパラメータは表-4に示す。なお，経路選択行動は，平 成13年長野都市圏PT調査データに基づいているため, 21 地区の支所を含むゾーンは，PT調査で設定されたゾー

表-4 パラメータの設定

\begin{tabular}{|c|c|c|}
\hline \multirow{2}{*}{\multicolumn{2}{|c|}{$\begin{array}{l}\text { 効用関数パラメータ【式(4)】 } \\
\text { ※長野市での行動調査分析に基づく }\end{array}$}} & $\beta=-0.054$ \\
\hline & & $\gamma=-2.825$ \\
\hline \multirow{2}{*}{\multicolumn{2}{|c|}{$\begin{array}{l}\mathrm{BPR} \text { 関数パラメータ【式(6)】 } \\
\text { ※米国道路局マニュアルに基づく }\end{array}$}} & $\kappa=0.15$ \\
\hline & & $v=4$ \\
\hline $\begin{array}{l}\text { 交通量軽減係数【式(6)】 } \\
\text { ※金沢市での調査に基づく }\end{array}$ & $\begin{array}{l}\text { 駆けつけ } \\
\text { 搬送 }\end{array}$ & $\begin{array}{l}\eta=0.35 \\
\eta=0.70\end{array}$ \\
\hline \multicolumn{2}{|c|}{ 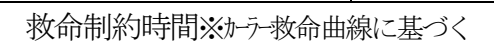 } & $t_{d}=30$ 分 \\
\hline \multicolumn{2}{|c|}{$\begin{array}{c}\text { 日々の学習係数【式(2)(3)】 } \\
\text { ※京都大学等での室内実験に基づく }\end{array}$} & $\begin{array}{l}\omega_{e}=0.40 \\
\omega_{v}=0.40\end{array}$ \\
\hline
\end{tabular}
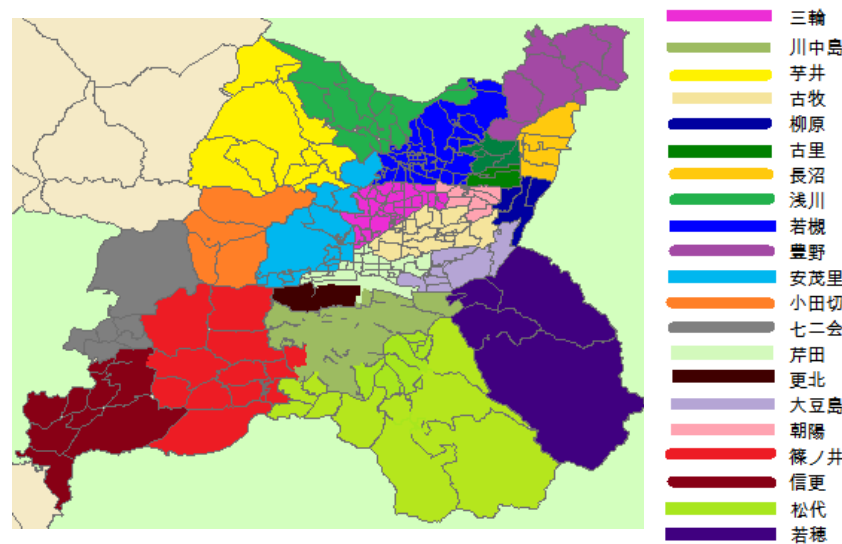

図-5＼cjkstart長野都市圈の各支所のゾーン図
ンに基づいて設定した.ゾーンは図-5に示す.

\section{（2）救命時間信頼性アクセシビリティ分析}

消防署・分署と後方病院の組み合わせごとに得られる 時間信頼性のうちの最大值に基づき，各地区の救命制約 時間信頼性を図-6と7に，式(10)を用いた救命ACを図-8 と9に示す. 通常時の閉塞リンクが1本もないケース 1 と, 非常時(災害時)の閉塞可能性のある47本のリンクがす心゙ て通行不可となるケース 2 にいて評価を行う。なお駆 けつけ搬送経路は，一番時間信頼度の高い経路を採用し て評価を行った.

図-6と 7 は，時間信頼性を 6 段階に分け，21 のゾー ンに色別で示したものである. 赤色に近づく程，制約時 間である 30 分以内の到着が難しくなることを示してい る. 図-6より, 長野市市街地および国道などの幹線沿 いの地区に消防署・分署が配置されている場合が多く, 市街地および幹線沿いの地区は時間信頼性が高いことが わかる。一方，市街地郊外および中山間地は所要時間が かかるため，時間信頼性が低下していることがわかる. しかしながら，救命制約時間信頼性が極端に低い $30 \%$ 以下の地区はないことがわかる．つぎに閉塞可能性のあ る市内 47 本のリンクがすべて通行不可となった場合, 図-7について，若穂では千曲川にかかる橋梁の被害に より，救命制約時間信頼性が 30\%以下になっている. また，芋井および信更地区などの中山間地域では，斜面

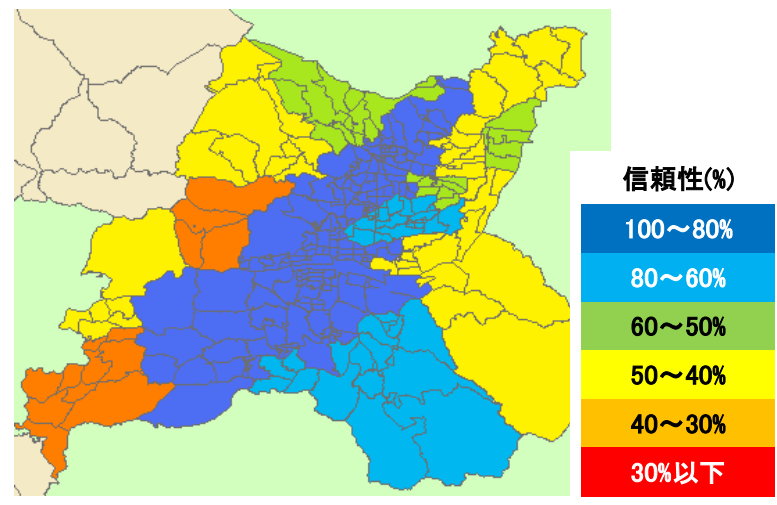

図-6 ケース1の救命制約時間信頼性分布

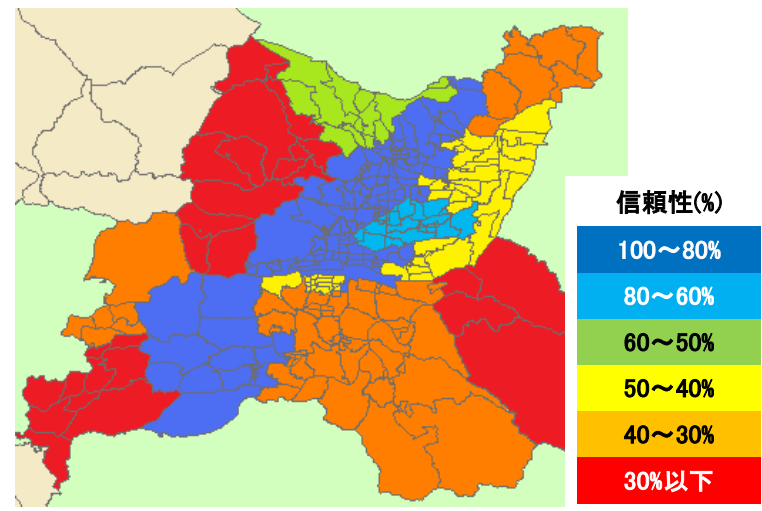

図-7 ケース2の救命制約時間信頼性分布 


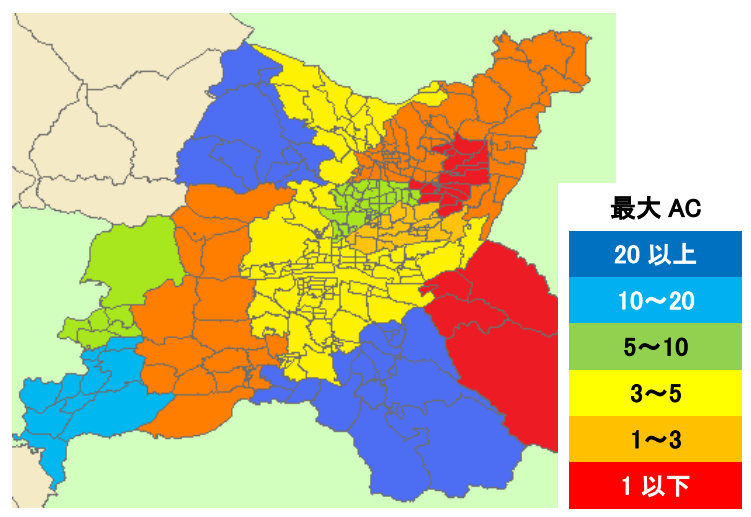

図-8 ケース1の救命AC分布

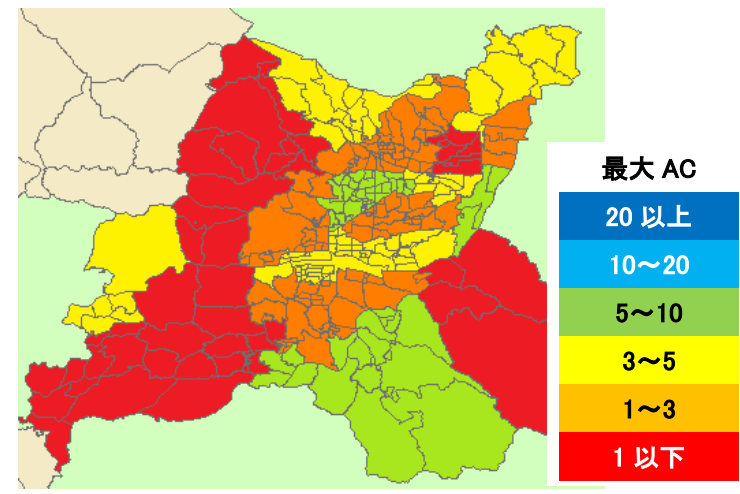

図-9 ケース 2 の救命AC分布

の切り土によるリンクが多く，地震後の通行不可により， 時間信頼性が 30\%以下となっている.

救命ACは，重傷者が同時多発的に発生する場合に， 対応できる救急車両数を考慮に入れた指標であり，一人 当たりの最小救命制約時間信頼性の意味合いを持つ. 図 -8では，図-6と比較すると，中心市街地およびその周辺 であってもAC值は低いことがわかる，三輪地区を除き， 中心市街地であってもAC值が低下していることがわか る. $\mathrm{AC}$ 值が1\%に満たない古里地区は古い木造住宅が多 く，重傷者数が多いことからAC值が低下してしまって いる．通行不可のリンクが47本存在する場合の図-9では, 全体的にAC值が低下してしまっているが，朝陽地区お よび柳原地区の $\mathrm{AC}$ 值は高くなっている。これは，通行 不可のリンクによって通常時に救命制約時間信頼性が最 大となる分署からの駆付けではなく，複数の救急車両を 持つ中央消防署から駆りけるためである.

\section{6. 適正な駆けつけ搬送圏域に関する考察}

\section{（1） AC指標に基づく駆けつけ搬送圏域の決定}

救急駆けつけ搬送体制として位置付けられている消防 署・分署および後方病院は市内に点在している. 被災地 区に対する消防署・分署と後方病院の適正な組み合わせ を検討することは, 救命率を可能な限り担保するために も必要不可欠と考える. ここでは, 救命AC指標值を最

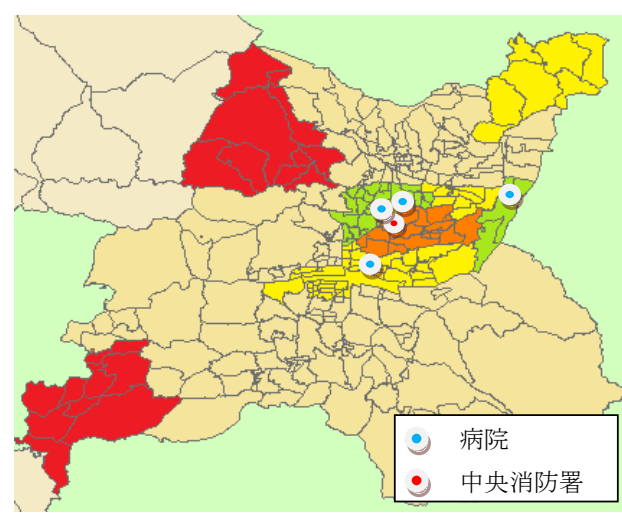

図-10 中央消防署勢力圏 (市内通行不可リンク 47本)

大にする消防署・分署と後方病院，および駆けつける被 災地の組み合わせを示し，消防署・分署の適正な駆けつ け搬送圈域について考察する。したがって，式(10)に基 づき, 被災地浘とって最適な消防署・分署 $l^{*}$, 後方病院 $k^{*} の$ 集合N $\left.l^{*}, k^{*} \mid j, j=1,2, \cdots, J\right)$ を求める. なお，駆けつけ搬 送経路が複数存在する場合，最も信頼度が高い経路を採 用した。

$$
C_{j \mid i, k} \rightarrow \max
$$

以下，駆けつけ搬送圈域を消防署・分署の勢力圈と呼 ぶ．なお，紙面の都合上，中央消防署の勢力圈を具体的 事例として示す.

\section{（2） 中央消防署の駆けつけ搬送勢力圏}

ここでは非常時(地震災害時)を対象に，式(13)にもと づいて得られた集合 $\mathrm{N}\left(i^{*}, k^{*} \mid j, j=1,2, \cdots, J\right)$ のなかで，中央 消防署から出動した救急車両によってACが最大となる 被災地 jおよび後方病院 $k^{*}$ の集合 $\mathbf{Z}\left(j^{\prime}, k^{*} \mid i\right)$ を図-10に示寸.

本結果から中央消防署は市内全域のうち $48 \%$ もの地区 を分担することになる．中央消防署が存在する古牧地区 のAC值が低いのは，地震被災時に㺟川にかかる橋梁の 被災により最短経路が通行不可となるためである。また， 芋井地区および信更地区への駆けつけは中央消防署から の交通ネットワークが連結されているだけで, 所要時間 がかかるためAC值は極めて低い結果となった。

\section{7. まとめ}

本研究では, 信濃川断層帯を震源とした地震が発生し た場合の長野市の重傷者数および道路の閉塞状況を整理 した．また，所要時間およびその変動を考慮した救命制 約時間信頼性評価を行うとともに，消防署の保有する救 急車両数および同時多発する重傷者数を考慮したアクセ シビリティによって，より実態に則した駆けつけ搬送体 制の機能評価を行った.さらに，各地区の $\mathrm{AC}$ 值に基づ いた駆けつけ搬送の最適な勢力圈を示した. 本手法によ って, 各地区ごとに救命制約時間信頼性が高い消防署・ 
分署および後方病院の組み合わせを考慮した駆けつけ搬 送を検討できることを示した，以下，本研究から得られ た知見を述べる.

（1）災害時では，救命制約時間信頼性が大きく低下す る地区が存在することから, 災害時の通行不可リンクを 考慮した駆けつけ搬送の配車を検討寸る必要がある.

（2）地区によって重傷者数が大きく異なることから, 市内各地区の重傷者発生分布を考慮した救急車両数の配 置を検討する必要がある.

（3）地震被災後は，通行不可リンクが多発し，孤立す る地区が存在するだけでなく，孤立して機能しない消防 署・分署および後方病院も存在するので，消防署・分署， 後方病院の再編を検討する必要がある.

（4）最寄りの消防署・分署がリンク通行不可のため, 規模の大きな消防署からの駆けつけで $\mathrm{AC}$ 值が上昇した 地区もある．被害状況によっては，規模の大きな消防署 からの駆けつけ要請を行う必要性も確認できた.

（5）災害時のリンク閉塞情報をリアルタイムで提供す ることで，より適切な駆けつけ搬送を行うことができる

（6）今後, 震度の生起確率とリンク通行不可の確率の 関係が明らかになることで，式(12)で示した各地区の総 $\mathrm{AC}$ を用いて，消防署・分署などの救急拠点および後方 病院などの搬送拠点の適切な配置を検討する必要がある。 また，今回，重傷者数の算定には，長野県地震対策基礎 調査報告書が提示しているモデル式を用いたが，今後， 地震被災と重傷者数の関係に関するデータの蓄積による， より精度の高いモデルを用いた信頼性の高い被害の検証 については, 今後の課題としたい.

\section{参考文献}

1）長野県危機管理室:平成 14 年長野県地震対策基礎調查報告 書, 長野県, 2002 年 3 月.

2)高山, 中山, 中野, 辰野：3 次救急医療を対象とした高速道 路救急車専用退出路の設置位置の選定, 第45回土木計画学研 究・講演集, 274, 2012.6
3)阪田, 坂本，中嶌他 : 高速道路整備による死亡リスク削減便 益の計測, 第45回土木計画学研究・講演集, 275, 2012.6

4) 二神, 池田 : 四国における救急搬送時間の短縮効果に関する 考察，第45回土木計画学研究・講演集，271，2012.6

5) 大橋 : 医療関係施設への所要時間と許容時間に関する居住都 市規模別調查, 第45回土木計画学研究・講演集, 276 , 2012. 6

6)稲川, 古田, 鈴木 : 救急車の配置計画における確率的評価指 標とその重要性について, 日本都市計画学会学術論文集, pp. 469-474, 2007. 11.

7) 高山, 黒田 : 救急車の走行時間信頼性からみた救急拠点の最 適配置に関する研究, 日本都市計画学会学術論文集, pp. 595-600, 2000. 10.

8) 秦, 高山, 中山 : 東日本大震災発生時における救急搬送の実 態と課題, 第45回土木計画学研究・講演集, $278,2012.6$

9)陶山，秋山，奥嶋 : 都市道路網における緊急時交通情報提供 の効率的運用に関する検討, 第 23 回交通工学研究発表会, 論文報告集，pp. 201-204，2003.10

10)瀬戸，宇野，塩見 : 非重複経路を考慮したアクセシビリテ イ指標に基づく医師配置計画モデルの構築, 日本都市計画学 会学術論文集, pp.487-492，2010.11.

11) 尾曽真理恵, 柳沢吉保, 古本吉倫, 高山純一, 和泉佑紀 : 救命制約時間を考慮した救急車両の地震被災地への未到達危 険度評価. 土木計画学研究 - 講演集 No. 42, 講演番号 117 , 2010.11

12)飯田, 柳沢, 内田 : 通勤交通の経路選択と出発時刻分布の 同時推定法，土木計画学研究・論文集 No.9pp.93-100,1991.11

13)飯田, 柳沢, 内田 : 通勤ドライバーの出発時刻と経路の同 時選択に関する行動分析，交通工学，Vol.28 No.6PP.11-20,1993

14)高山純一，柳沢吉保ほか：ITS を活用した救急車両の走行支 援ならびに最適配置計画策定システムの開発研究，基盤研究 (B)(2)研究成果報告書, pp.49, 2004.3

15)内田 敬 : 情報提供を考慮した動的経路選択の交通行動分析 に関する研究，京都大学学位論文，pp. 113-136, 1993.12

\section{EVALUATION OF TRAVEL TIME RELIABILITY OF EMERGENCY CAR WITH A LIMIT TIME TO LIFE-SAVING}

\section{Yoshiyasu YANAGISAWA, Yoshinori FURUMOTO, Jun-ichi TAKAYAMA, Satomi MINAMISAWA and Marie OSO}

This paper discusses transportation network reliability in time of disaster and the evaluation of emergency conveyance service framework. Analyzing the present condition of an emergency business, in this study we examine the optimal location of fire stations and first-aid station. We propose an accessibility indicator of the travel time reliability to the urgent medical institution of an ambulance. In this paper, the above method is applied to Nagano urban area. In the experimental study, we verified location of fire stations and first-aid station affects a limit time to life-saving. We confirmed accessibility indicator practicality. 